\title{
Menelaah Keadilan dalam Kebijakan Penanggulangan Illegal Fishing Di Indonesia: Perspektif Konsep Keadilan Thomas Aquinas
}

\author{
Mashuril Anwar ${ }^{1 *}$, Rini Fathonah ${ }^{2}$, Niko Alexander ${ }^{3}$ \\ 1,2,3 Program Magister Ilmu Hukum Universitas Lampung, Lampung, Indonesia \\ *E-mail: mashurilanwar97@gmail.com
}

Dikirim: 22/06/2020

\begin{tabular}{l}
\hline Info Artikel \\
\hline Keywords: \\
Justice; \\
Illegal Fishing; \\
Thomas Aquinas. \\
\\
Keadilan; \\
Thomal Fishing; \\
Kata Kunci: \\
\hline
\end{tabular}

Direvisi: 29/03/2021

Dipublikasi: 04/06/2021

\section{Abstract}

Justice is still an expensive item that is difficult to reach by every level of Indonesian society, including local fishermen who do illegal fishing. The criminal law policy in tackling illegal fishing which is represented in the Fisheries Law is not proportional and does not have a clear measure. Therefore, in the case of illegal fishing, a discourse of justice is attached. Related to the concept of justice offered by Thomas Aquinas, which emphasizes equality, justice, and the policy of tackling illegal fishing in Indonesia, it is interesting to discuss. This article aims to examine funds to analyze the concept of Thomas Aquinas 'philosophy of justice and to explore justice in the policy of tackling illegal fishing in the perspective of Thomas Aquinas' philosophy of justice. In order to answer these problems, this study uses a normative juridical method. Based on the research results, the concept of justice offered by Thomas Aquinas consists of distributive, commutative, and indicative justice. The essence of Thomas Aquinas' three concepts of justice is proportional to equality. Associated with Thomas Aquinas' concept of justice, the policy to combat illegal fishing in Indonesia has not provided justice. It is said that because the sanction for deprivation of freedom in the Fisheries Law only applies to local fishermen and has not reached foreign fishermen who do illegal fishing. In order to be fair, the sanction of deprivation of liberty should not apply to local fishermen who do illegal fishing as well as foreign fishermen.

\footnotetext{
Abstrak

Keadilan masih menjadi barang mahal yang sulit dijangkau oleh setiap lapisan masyarakat Indonesia, termasuk nelayan lokal pelaku illegal fishing. Kebijakan hukum pidana dalam penanggulangan illegal fishing yang direpresentasikan dalam Undang-Undang Perikanan tidak proporsional dan tidak memiliki ukuran yang jelas. Oleh karena itu dalam perkara illegal fishing melekat diskursus keadilan. Dikaitkan dengan konsep keadilan yang ditawarkan Thomas Aquinas yang menekankan pada persamaan, keadilan dan kebijakan penanggulangan illegal fishing di Indonesia menarik untuk dibahas. Artikel ini bertujuan mengkaji dana menganalisis konsep filsafat keadilan Thomas Aquinas dan menelusuri keadilan dalam kebijakan penanggulangan illegal fishing dalam perspektif filsafat keadilan Thomas Aquinas. Guna menjawab permasalahan tersebut, penelitian ini menggunakan metode yuridis normatif. Berdasarkan hasil penelitian,
} 
DOI:

10.47268/sasi.v27i2.357

konsep keadilan yang ditawarkan Thomas Aquinas terdiri dari keadilan distributif, komutatif, dan vindikatif. Esensi dari ketiga konsep keadilan Thomas Aquinas tersebut adalah keselarasan atau persamaan yang proporsional. Dikaitkan dengan konsep keadilan Thomas Aquinas tersebut, kebijakan penanggulangan illegal fishing di Indonesia belum memberikan keadilan. Dikatakan demikian karena sanksi perampasan kemerdekaan dalam Undang-Undang Perikanan hanya berlaku bagi nelayan lokal dan belum menjangkau nelayan asing pelaku illegal fishing. Agar dapat dikatakan adil, seharusnya sanksi perampasan kemerdekaan tidak berlaku juga bagi nelayan lokal pelaku illegal fishing seperti halnya terhadap nelayan asing.

\section{A. PENDAHULUAN}

Sepanjang perjalanan filsafat hukum, keadilan merupakan salah satu cita hukum yang selalu menjadi perhatian. ${ }^{1}$ Hal ini dikarenakan keadilan merupakan ide yang faktual dan relevan dengan dinamika peradaban manusia, dan keadilan selalu bersentuhan dengan kodrat manusia sebagai animal sociale dan animal politicum. ${ }^{2}$ Keadilan itu sendiri memiliki banyak dimensi baik ekonomi, sosial, politik, dan hukum. Sehingga sering kali terdapat perbedaan penafsiran mengenai parameter keadilan. ${ }^{3}$ Memahami keadilan harus selalu dikaitkan dengan kehidupan yang nyata, dalam konteks Indonesia yakni keadilan terkait dengan ketertiban kehidupan berbangsa dan bernegara serta keadilan terkait kesejahteraan sosial sebagaimana yang diamanatkan oleh UUD RI Tahun $1945 .^{4}$

Masalah keadilan masih menjadi persoalan dalam penegakan hukum di Indonesia. Bahkan dapat dikatakan bahwa saat ini bangsa Indonesia sedang mengalami krisis keadilan dalam penegakan hukum. ${ }^{5}$ Penegakan hukum di Indonesia semata-mata hanya berorientasi pada kepastian hukum dan mengabaikan aspek keadilan bagi masyarakat. ${ }^{6}$ Penegakan hukum di Indonesia saat ini belum sepenuhnya mencerminkan keadilan bagi masyarakat. Keadilan masih menjadi barang mahal yang sulit dijangkau oleh masyarakat. Berbagai perkara hukum sering kali mencuat dan menjadi perbincangan karena dianggap telah mengabaikan keadilan yang sepatutnya dinikmati masyarakat. ${ }^{7}$ Penegakan hukum yang tidak sejalan dengan keadilan dalam masyarakat merupakan gejala yang mengkhawatirkan karena berdampak pada hilangnya keperayaan masyarakat pada penegak hukum suatu negara. ${ }^{8}$

Beberapa ahli telah mengemukakan teori keadilan dalam kajian filsafat. Thomas Aquinas adalah salah satu ahli yang mengembangkan konsep keadilan yang menekankan pada persamaan status dan persamaan hak dan kewajiban secara proporsional. ${ }^{9}$ Dalam questiones

1 Amin, M. (2014). Konsep Keadilan Dalam Perspektif Filsafat Hukum Islam. Al-Daulah: Jurnal Hukum dan Perundangan Islam, 4(02), 322-343. DOI: https://doi.org/10.15642/ad.2014.4.02.322-343, h. 323.

2 Arum, G. A. (2019). Konsep Keadilan (Iustitia) Perspektif St. Thomas Aquinas dan Relevansinya Bagi Pemaknaan Sila V Pancasila. Lumen Veritatis: Jurnal Filsafat dan Teologi, 10(1), 23-44. DOI: $<$ https://doi.org/10.30822/lumenveritatis.v10i1.207>, h. 23.

3 Dwisvimiar, I. (2011). Keadilan dalam perspektif filsafat ilmu hukum. Jurnal Dinamika Hukum, 11(3), 522-531. DOI: https://doi.org/10.20884/1.jdh.2011.11.3.179, h.522.

4 Nasution, B. J. (2014). Kajian Filosofis tentang Konsep Keadilan dari Pemikiran Klasik sampai Pemikiran Modern. Yustisia Jurnal Hukum, 3(2). DOI: https://doi.org/10.20961/yustisia.v3i2.11106, h. 119.

5 Rahardjo, S. (2003). Sisi-sisi lain dari Hukum di Indonesia. Jakarta: Penerbit Buku Kompas.

6 Suhardin, Y. (2009). Fenomena Mengabaikan Keadilan dalam Penegakan Hukum. Mimbar HukumFakultas Hukum Universitas Gadjah Mada, 21(2), 341-354. DOI: https://doi.org/10.22146/jmh.16261. h. 341.

7 Sutiyoso, B. (2010). Mencari Format Ideal Keadilan Putusan dalam Peradilan. Jurnal Hukum Ius Quia Iustum, 17(2), 217-232. DOI: https://doi.org/10.20885/iustum.vol17.iss2.art5, h. 218.

8 Wantu, F. M. (2013). Kendala Hakim Dalam Menciptakan Kepastian Hukum, Keadilan, dan Kemanfaatan di Peradilan Perdata. Mimbar Hukum-Fakultas Hukum Universitas Gadjah Mada,25(2), 205-218. DOI: https://doi.org/10.22146/jmh.16092, h 208.

9 Adlhiyati, Z., \& Achmad, A. (2019). Melacak Keadilan dalam Regulasi Poligami: Kajian Filsafat 127|SASI Vol. 27 No.2, April - Juni 2021 
58 articulis 1 summa theologiae parssecunda secundaer, Thomas Aquinas menegaskan keadilan sebagai "Iustitia est habitus secundeum quem aliquis constanti et perpetua voluntate ius suum unicique tribuit" (keadilan adalah kebiasaan dimana seseorang dengan kehendak yang konstan dan tetap memberikan kepada setiap orang apa yang menjadi haknya). ${ }^{10}$ Selanjutnya Thomas Aquinas membagi keadilan menjadi dua yakni keadilan duniawi dan keadilan ilahi. Namun demikian Thomas Aquinas tidak mempertentangkan kekuasaan gereja dan kekuasaan duniawi. Menurutnya konsep keadilan yang ditetapkan oleh agama sepenuhnya sejalan dengan akal manusia yang direpresentasikan dalam ketentuan hukum. ${ }^{11}$

Thomas Aquinas salah seorang filsuf yang besar di lingkungan gereja, pemikirannya sangat dipengaruhi oleh relegiusitas kristiani. Pemikirannya lebih mengarah pada tercapainya kepentingan umum dalam masyarakat dari pada validitas sebuah aturan. ${ }^{12}$ Sebagai filsuf yang menekankan keadilan sebagai persamaan, Thomas Aquinas membagi konsep keadilan menjadi dua. Pertama, keadilan umum yang berkaitan dengan relasi antar manusia dengan memberikan apa yang menjadi haknya. Kedua, keadilan khusus yang terdiri dari keadilan distributif, komutatif, dan keadilan vindikatif. Keadilan distributif menekankan pada pembagian hak dan kewajiban secara proporsional. Keadilan komutatif menekankan pada interaksi melalui pertukaran atar invidu. Sedangkan keadilan vindikatif mengarah kepada pembalasan yang setimpal. $^{13}$

Dikaitkan dengan teori keadilan yang dikemukan Thomas Aquinas tersebut, keadilan dan Illegal fishing menjadi menarik untuk dibahas. Dalam perkara illegal fishing melekat diskursus keadilan. Praktik illegal fishing tidak hanya berdampak buruk bagi lingkungan, namun menimbulkan dampak sosial yakni melukai rasa keadilan nelayan lokal. Dikatakan demikian karena kebijakan hukum pidana dalam penanggulangan illegal fishing yang tercantum dalam Undang-Undang Nomor 31 Tahun 2004 juncto Undang-Undang Nomor 45 Tahun 2009 tentang Perikanan (Undang-Undang Perikanan) tidak proporsional dan tidak memiliki ukuran yang jelas. Sanksi bagi nelayan lokal pelaku illegal fishing lebih berat dari pada pelaku yang berkewarganegaraan asing. Sanksi pidana badan (kurungan dan penjara) hanya berlaku bagi nelayan lokal. Sedangkan pelaku illegal fishing yang berkewarganegaraan asing tidak dapat dijatuhi sanksi pidana badan baik penjara maupun kurungan, karena dibatasi oleh ketentuan Pasal 73 UNCLOS 1982 yang diadopsi oleh Pasal 102 Undang-Undang Perikanan. Padahal praktik illegal fishing yang dilakukan oleh nelayan asing maupun nelayan lokal sama-sama berpotensi menimbulkan kerusakan lingkungan dan kerugian materil. Namun konstruksi Undang-Undang Perikanan tidak menempatkan nelayan lokal dan nelayan asing pelaku illegal fishing dalam posisi yang setara atau sederajat.

\section{B. METODE PENELITIAN}

Guna menjawab permasalahan dalam penelitian ini, penulis menggunakan pendekatan yuridis normatif yang bersifat deskriptif analitis. Penelitian yuridis normatif merupakan penelitian yang bertujuan mencari kaidah dan norma. ${ }^{14}$ Penelitian ini menggunakan data sekunder yang bersumber pada studi kepustakaan seperti artikel, buku, hasil penelitian dan

\footnotetext{
Keadilan Aristoteles, Thomas Aquinas, dan John Rawls. Undang: Jurnal Hukum, 2(2), 409-431. DOI: https://doi.org/10.22437/ujh.2.2.409-431, h. 412.

10 Arum, G. A. (2019). Op Cit, h. 25.

11 Surajiyo, S. (2018). Keadilan Dalam Sistem Hukum Pancasila. IKRA-ITH HUMANIORA: Jurnal Sosial dan Humaniora, 2(3), 21-29, h. 24

12 Vieru, S. (2010). Aristotle's Influence on the Natural Law Theory of St Thomas Aquinas. The Western Australian Jurist, 1, 115-122, h. 1.

13 Erwin, M. (2016). Filsafat Hukum Refleksi Kritis terhadap Hukum Indonesia (dalam Dimensi Ide dan Aplikasi). Jakarta: Raja Grafindo Persada.

14 Wantu, F. M. (2013). Op Cit, h. 207.
}

$$
\text { 128|S A S I Vol. } 27 \text { No.2, April - Juni } 2021
$$


literatur terpercaya lainnya. ${ }^{15}$ Pengumpulan data dalam penelitian ini dilakukan dengan cara membaca, mengutip, dan menelaah. Selanjutnya data yang diperoleh dianalisis dengan metode deskriptif kualitatif.

\section{PEMBAHASAN}

\section{Filsafat Keadilan dalam Perspektif Thomas Aquinas}

Keadilan merupakan bagian yang tidak terpisahkan dari cita hukum itu sendiri. Sebagai bagian dari nilai sosial, keadilan memiliki makna yang amat luas. Hal inilah yang menarik perhatian para filsuf Yunani kuno untuk memikirkan persoalan keadilan. Thomas Aquinas salah satu filsuf Yunani yang yang banyak memberikan pandangan mengenai keadilan. Thomas Aquinas (1225-1274 M) merupakan salah seorang filsuf yang mengembangkan pemikiran pendahulunya yakni Aristoteles (384-322 SM). ${ }^{16}$ Potensi Thomas Aquinas sudah terlihat sejak ia berusia 5 tahun. Pada usia 20 tahun ia menjadi biarawan dan berguru pada Albert the Great (1200-1280 M). Albert the Great sendiri merupakan seorang filsuf yang banyak mendalami pemikiran Aristoteles melalui terjemahan Arab-Yunani. ${ }^{17}$

Menurut Thomas Aquinas, keutamaan dari keadilan yakni "aliquod opus adaequantum alteri secundum aliquem aequalitatis modum", yakni sesuatu yang sepatutnya bagi orang lain berdasarkan kesamaan proporsional. ${ }^{18}$ Thomas Aquinas menyatakan bahwa disamping kesederhanaan, keteguhan, dan kebijaksanaan, keadilan merupakan salah satu keutaman hidup. Keutamaan ini berhubungan dengan akal, budi, emosi, dan kehendak. ${ }^{19}$ Keadilan menurut konsep Thomas Aquinas adalah kesetaraan. Menurutnya keadilan terkait mengenai apa yang seharusnya diterima oleh seseorang menurut suatu kesamaan proporsional. ${ }^{20}$

Thomas Aquinas membedakan keadilan menjadi dua, yakni keadilan umum (iustitia generalis) dan keadilan khusus (iustitia specialis). Keadilan umum merupakan konsep keadilan yang berkaitan dengan hubungan antar manusia dengan memberikan apa yang menjadi haknya. ${ }^{21}$ Keadilan umum merupakan keadilan yang dikehendaki undang-undang yang harus dilaksanakan demi kepentingan umum. Pendapat Aquinas ini ditanggapi oleh Gilby, yang menyatakan bahwa keadilan merupakan nilai analogis yang ditempatkan di berbagai tingkatan/hierarki sesuai dengan yang seharusnya terjadi karena kebaikan bersama komunitas politik (justitia generalis), antar orang perorangan (justitia commutativa), dan antar orang perorangan dengan kelompok politik (justitia distributiva). ${ }^{22}$ Sedangkan menurut Albert the Great dalam bukunya Summa de Bono dinyatakan bahwa Umumnya keadilan dipahami dengan tiga cara. Dalam salah satu cara ini tidak disebutkan kebajikan khusus, tetapi lebih baik disebut kebajikan umum. Menurut Albert, efek kasih dan karunia dalam kebajikan adalah keadilan umum yang menyebabkan orang tidak berlaku adil. Namun menurut Albert keadilan juga dipahami dengan dua cara yaitu semua kebiasaan bertindak dalam diri masing-masing orang. Kemudian keadilan umum juga dipahami sesuai dengan kodrat manusia.

Berdasarkan konsep keadilan umum Thomas Aquinas, esensi keadilan bertujuan untuk mengarahkan manusia pada kebajikan umum (bonum commune). Oleh karena itu keadilan

15 Siregar, C. (2014). Pancasila, Keadilan Sosial, dan Persatuan Indonesia. Humaniora, 5(1), 107-112.. DOI: https://doi.org/10.21512/humaniora.v5i1.2988, h. 108.

16 Vieru, S. (2010). Op Cit, h. 115. .

17 Ibid, h. 118 .

18 Ibid.

19 Adlhiyati, Z., \& Achmad, A. (2019). Op Cit, h. 419.

20 Srisusilawati, P., \& Eprianti, N. (2017). Penerapan prinsip keadilan dalam akad mudharabah di lembaga keuangan syariah. Law and Justice, 2(1), 12-23. DOI: https://doi.org/10.23917/laj.v2i1.4333, h. 15.

21 Ibid.

22 Lisska, A. J. (2015). The Philosophy of Law of Thomas Aquinas. In A Treatise of Legal Philosophy and General Jurisprudence (pp. 285-310). Dordrecht: Springer, h. 308. 
disebut juga sebagai kebajikan umum (virtus generalis). ${ }^{23}$ Namun keadilan umum tidak hanya mengikuti hukum masyarakat, tetapi lebih kepada kebiasaan yang telah berakar dalam mengikuti dikte atau arahan hukum kodrat. ${ }^{24}$

Selanjutnya keadilan khusus menurut Thomas Aquinas terdiri dari keadilan distributif (justitia distributiva), keadilan komutatif (justitia commutativa), dan keadilan vindikatif (justitia vindivativa). ${ }^{25}$

\section{a. Keadilan distributif (justitia distributiva)}

Keadilan distributif yang dikemukan Thomas Aquinas pada dasarnya merupakan reinkarnasi dari keadilan distributif yang digagas Aristoteles, melalui pembagian hak dan kewajiban secara proporsional. Keadilan distributif merupakan bentuk penghormatan atas keluhuran person manusia. ${ }^{26}$ Keadilan distributif merupakan konsep keadilan yang menghendaki setiap orang memperoleh apa yang menjadi haknya secara proporsional. ${ }^{27}$ Oleh karena itu, keadilan tidak dicapai dengan semata-mata menetapkan nilai aktual, namun didasari pula oleh kesamaan antar suatu hal dengan hal lainnya (aequalitas rei adrem). ${ }^{28}$ Dalam konteks penegakan hukum tentunya ketentuan hukum harus didasarkan pada keadilan distributif, kesesuaian hukuman dengan tindakan yang dilakukan, dan kemanfaatan secara sosial. ${ }^{29}$ Selanjutnya dalam konteks pemerintahan, keadilan distributif merupakan bentuk keadilan yang menata hubungan negara dengan masyarakat. Dalam kaitannya dengan sistem pemerintahan, keadilan distributif mengacu kepada peran sistem pemerintahan dan pemerintahnya dalam mendistribusikan hak dan kewajiban secara adil dan proposional bagi setiap anggota masyarakat. ${ }^{30}$ Hal ini sebagaimana ditegaskan oleh Thomas Aquinas: "Alius ordo attenditur totius ad partes, et huic ordini assimilatur ordo eius quod est commune ad singulas personas. Quim quidem ordinem dirigit iustitia distibutiva quae est distributiva communium secundum proportionalitatem" yang berarti bahwa di tempat yang lain, ada hubungan antara keseluruhan terhadap bagian-bagiannya, yang menghubungkan relasi keteraturan dari apa yang menjadi milik komunitas dalam hubungannya dengan setiap individu. Hubungan ini diatur oleh keadilan distributif, yang mendistribusikan hak-hak umum secara proporsional. ${ }^{31}$

\section{b. Keadilan komutatif (justitia commutativa)}

Kajian filsafat hukum mempersoalkan pertanyaan-pertanyaan mendasar tentang hukum. ${ }^{32}$ Sebagai cita hukum tertinggi, keadilan merupakan salah satu tujuan filosofis

23 Arum, G. A. (2019). Op Cit, h. 25.

24 Bushlack, T. J. (2011). Justice in the theology of Thomas Aquinas: Rediscovering civic virtue. University of Notre Dame.

${ }^{25}$ Sumaryono, E., \& Sardi, M. (2002). Etika \& hukum: relevansi teori hukum kodrat Thomas Aquinas. Jakarta: Kanisius.

26 Harnoko, A. Y., \& Ratnawati, I. Y. (2015). Asas Proporsional dalam Perjanjian Waralaba (Franchise). Jurnal Hukum Bisnis, 1(1). DOI:https://doi.org/10.33121/hukumbisnis.v1i1.54, h. 9.

27 Nasution, B. J. (2016). Kajian Filosofis tentang Hukum dan Keadilan dari Pemikiran Klasik Sampai Pemikiran Modern. Al-Ihkam: Jurnal Hukum \& Pranata Sosial,11(2), 247-274. DOI: 10.19105/alihkam.v11i2.936, h. 253.

28 Hernoko, A. Y. (2009). Perkembangan dan Dinamika Hukum Perdata Indonesia-Dalam Rangka Peringatan Ulang Tahun Ke-80 Prof. Dr. Mr. R. Soetojo Prawirihamidjojo, SH, Lutfansah Mediatama. Prof. Dr. Mr. R. Soetojo Prawirihamidjojo, SH, Surabaya: Lutfansah Mediatama, h. 20.

29 Putra, S. D. E. (2016). Bingkai Keadilan Hukum Pancasila Dalam Perspektif Hukum Dan Relevansinya Dengan Keadilan Di Indonesia. Jurnal Ilmiah Pendidikan Pancasila dan Kewarganegaraan, 27(1). DOI: http://dx.doi.org/10.17977/jppkn.v27i1.5515, h. 54.

30 Arum, G. A. (2019). Op Cit, h. 27.

31 Ibid.

32 Helmi, M. (2015). Konsep Keadilan Dalam Filsafat Hukum Dan Filsafat Hukum Islam. Mazahib, 14(2). DOI: https://doi.org/10.21093/mj/v14i2.342, h. 134.

$$
\text { 130|S A S I Vol. } 27 \text { No.2, April - Juni } 2021
$$


hukum. ${ }^{33}$ Keadilan komutatif atau keadilan kebersamaan tidak membedakan derajat atau kedudukan dalam kehidupan bermasyarakat. ${ }^{34}$ Hakekatnya bentuk keadilan komutatif merupakan relasi primer antar individu dalam masyarakat, atau keadilan yang mengatur hubungan interpersonal. Keadilan komutatif menghendaki pemberian kepada seseorang dengan sama banyaknya. Menurut keadilan komutatif, dikatakan adil apabila setiap orang memperoleh perlakuan yang sama dan merata tanpa membedakan status, kedudukan, gender, ${ }^{35}$ jasa, serta tidak ada perlakuan yang istimewa. ${ }^{36}$ Misalnya, pembagian beras di suatu pengungsian dikatakan adil apabila setiap orang memperoleh beras dengan sama banyaknya. ${ }^{37}$

\section{c. Keadilan vindikatif (justitia vindivativa)}

Keadilan vindikatif merupakan konsep keadilan yang menghendaki pemberian hukuman yang setimpal sesuai dengan perbuatan yang dilakukan. ${ }^{38}$ Keadilan vindikatif lebih cenderung pada tindakan pembalasan (represif). Menurut Aristoteles, pembalasan semacam ini lazim diterapkan pada bidang hukum pidana dengan porsi yang seimbang atau proporsional antara perbuatan dengan hukuman yang diberikan. ${ }^{39}$ Berdasarkan keadilan vindikatif, perlakuan terhadap seseorang dianggap tidak adil apabila pidana penjara atau denda yang dijatuhkan sesuai dengan besarnya hukuman yang telah ditentukan atas tindak pidana yang dilakukannya, melainkan harus setimpal dengan kerugian yang ditimbulkan oleh perbuatannya. ${ }^{40}$ Apabila ditelaah lebih lanjut, konsep keadilan vindikatif telah dianut oleh Indonesia. Konsep keadilan vindikatif diadopsi oleh Pasal 6 Undang-Undang Nomor 12 Tahun 2011 tentang Pembentukan Peraturan Perundang-Undangan, yang menentukan bahwa setiap materi muatan peraturan perundang-undangan harus mencerminkan keadilan secara proporsional bagi setiap warga negara. $^{41}$

\section{Keadilan dalam Kebijakan Penanggulangan Illegal Fishing di Indonesia Ditinjau dari Filsafat Keadilan Thomas Aquinas}

Konsep keadilan yang dikemukan Thomas Aquinas pada intinya menghendaki pemerataan atau persamaan hak, kewajiban, status, gender, kedudukan dan sebagainya. Kebijakan penanggulangan illegal fishing di Indonesia yang direpresentasikan dalam UndangUndang Perikanan telah mengakui pemerataan dalam pengelolaan perikanan. Pasal 2 huruf $b$ Undang-Undang Perikanan menentukan bahwa pengelolaan perikanan dilakukan berdasarkan asas keadilan. Pengelolaan perikanan harus mampu memberikan peluang dan kesempatan yang sama secara proporsional kepada seluruh warga negara tanpa terkecuali. Selanjutnya Pasal 2

33 Ramon, T. (2019). Kriteria Keseimbangan Dalam Perjanjian Kredit Bank Untuk Mewujudkan Keadilan Komutatif. Jurnal Hukum IUS QUIA IUSTUM, 26(2), $372-390 . \quad$ DOI: https://doi.org/10.20885/iustum.vol26.iss2.art8, h. 373.

34 Tim Penyusun. (2013). Naskah Akademik Hukum Kontrak. Jakarta: BPHN Kementerian Hukum dan HAM RI, h. 121.

35 Pratasis, S. O. (2014). Implementasi Teori Keadilan Komutatif Terhadap Pelaku Pemerkosaan Menurut Pasal 285 KUHP. LEX ET SOCIETATIS, 2(5), h. 57.

36 Suryawati, I. G. A. A., \& Santhiarsa, I. G. N. N. (2020). Literasi Budaya Bali: Kajian Filsafat Ilmu Tentang Keadilan Dalam Sistem Subak. Jurnal Nomosleca, 6(1). DOI: https://doi.org/10.26905/nomosleca.v6i1.3960. h. 48.

37 Mertokusumo, S. (2010). Mengenal Hukum; Suatu Pengantar. Yogyakarta: Cahaya Atma Pustaka, h. 102.

38 Mashuri, M. (2017). Teori Keadilan Dalam Perlindungan Hukum Bagi Kepala Desa Dalam Melaksanakan Kebijakan Desa (Studi Kasus Putusan Perkara Nomor 66/Pid. Sus/Tpk/2015/PN. Sby). MIMBAR YUSTITIA, 1(1), 59-78., h. 76.

39 Arifin, M. (1993). Teori dan Filsafat Hukum. Jakarta: Rajagrafindo Persada, h. 117.

40 Putra, A. P. (2015). Tanggung Jawab PT. PLN Terhadap Konsumen Akibat Pemadaman Listrik Ditinjau Dari UU No 8 Tahun 1999 Tentang Perlindungan Konsumen (Disertasi, Universitas Pembangunan Nasional Veteran Jakarta).

41 Harahap, D. R. S. (2020). Kebijakan Formulasi Tindak Pidana Oleh Anak Yang Dapat Diupayakan Diversi Berdasarkan Aspek Keadilan Dan Tujuan Pemidanaan. Ilmu dan Budaya, 41(67), h. 7869. 
huruf f Undang-Undang Perikanan menentukan bahwa pengelolaan perikanan dilakukan berdasarkan asas pemerataan, yakni pengelolaan yang dilakukan dengan seimbang dan merata dengan memperhatikan nelayan kecil dan pembudidaya ikan kecil. Ketentuan tersebut telah memberikan landasan bagi nelayan lokal untuk memperoleh perlakuan yang sama dalam pengelolaan perikanan, termasuk terhadap ketentuan pidana yang menjeratnya.

Namun disisi lain, Pasal 102 Undang-Undang Perikanan yang mengadopsi ketentuan Pasal 73 UNCLOS pada intinya menentukan bahwa ketentuan pidana badan (penjara dan kurungan) hanya berlaku bagi pelaku illegal fishing yang berkewarganegaraan Indonesia. Sedangkan penjatuhan sanksi pidana badan bagi pelaku illegal fishing yang berkewarganegaraan asing hanya dapat dilakukan apabila terdapat perjanjian bilateral dengan pemerintah negara yang bersangkutan. Disisi lain berdasarkan penelitian yang dilakukan oleh Kejaksaan Republik Indonesia, sebanyak 65,18\% responden menyatakan bahwa Indonesia belum memiliki perjanjian bilateral terkait penanganan pelaku illegal fishing. ${ }^{42}$ Selain itu, ketentuan Pasal 102 Undang-Undang Perikanan inkonsistensi dengan ketentuan Pasal 2 huruf $\mathrm{b}$ dan huruf $\mathrm{f}$ Undang-Undang Perikanan. Di satu sisi, Pasal 2 huruf $\mathrm{b}$ dan huruf $\mathrm{f}$ mengakui adanya kesetaraan bagi nelayan lokal dalam pengelolaan perikanan. Namun ketentuan Pasal 102 Undang-Undang Perikanan membedakan perlakuan dalam hal penjatuhan pidana terhadap nelayan lokal dan nelayan asing pelaku tindak pidana illegal fishing. Padahal praktik illegal fishing baik yang dilakukan oleh nelayan asing maupun nelayan lokal sama-sama berpotensi menimbulkan kerusakan lingkungan dan kerugian materil. Namun konstruksi Undang-Undang Perikanan tidak menempatkan nelayan lokal dan nelayan asing pelaku illegal fishing dalam posisi yang setara atau sederajat.

Mengacu pada konsep keadilan yang dikemukakan Thomas Aquinas yang menitikberatkan pada persamaan, maka seharusnya baik nelayan lokal maupun nelayan asing pelaku illegal fishing memiliki hak, kewajiban, dan kedudukan yang sama di hadapan hukum. Apabila nelayan asing pelaku illegal fishing hanya dapat dipidana badan jika ada perjanjian bilatreral, maka seharusnya ada batasan yang ketat pula dalam menjatuhkan pidana terhadap nelayan lokal pelaku illegal fishing. Di sisi lain, Undang-Undang Perikanan menganut prinsip pemidanaan kumulatif yakni penjatuhan pidana penjara dan denda secara bersamaan. Sedangkan bagi nelayan asing hanya dapat dijatuhi pidana denda tanpa disertai pidana pengganti kurungan apabila denda tidak dibayar. Hal ini tentu membuka peluang bagi nelayan asing pelaku illegal fishing untuk tidak membayat denda. Dalam praktinya apabila nelayan asing tidak mampu membayar denda maka denda yang tidak dibayarkan akan menjadi piutang negara yang harus dipertanggungjawabkan oleh kejaksaan sebagai eksekutor. Denda yang tidak dibayarkan akan menjadi piutang negara dan menjadi tunggakan kejaksaan dalam pelaporan PNBP dan tidak menimbulkan efek jera. ${ }^{43}$ Dengan demikian, pembedaan perlakuan antara nelayan lokal dan nelayan asing pelaku illegal fishing menyebabkan nelayan lokal lebih rentan dijatuhi pidana perampasan kemerdekaan. Karena dalam praktiknya, nelayan lokal pelaku illegal fishing umumnya tidak mampu membayar denda sehingga diganti dengan pidana kurungan. ${ }^{44}$ Berdasarkan konsep keadilan Thomas Aquinas, kondisi ini tentu tidak adil bagi nelayan lokal yang mayoritas memiliki kapal dan penghasilan yang relatif lebih kecil dibandingkan dengan nelayan asing.

Secara sosio-historis, ketidakadilan dalam pemidanaan pelaku illegal fishing ini disebabkan karena politik hukum pembentukan Undang-Undang Perikanan yang lebih mengedepankan tindakan represif dari pada tindakan preventif dan rehabilitatif. Tidak ditemukan satu pun ketentuan dalam Undang-Undang Perikanan yang menunjukkan niat pemerintah untuk melakukan tindakan restoratif khususnya bagi nelayan lokal pelaku illegal

42 Sunatri, T. (2017). Optimalisasi Pelaksanaan Eksekusi Pidana Denda Dikaitkan Pasal 102 UndangUndang Nomor 31 tahun 2004 Tentang Perikanan. Jakarta: MISWAR, h. 47.

43 Ibid. h. 115.

44 Ibid. 67-68.

132|SASI Vo1. 27 No.2, April - Juni 2021 
fishing. Kondisi ini tentu menyebabkan aparat penegak hukum lebih mengedepankan pemenjaraan terhadap pelaku illegal fishing. ${ }^{45}$

\section{PE N U T U P}

Konsep keadilan yang ditawarkan Thomas Aquinas menekankan pada kesetaraan atau persamaan. Berdasarkan konsep keadilan Thomas Aquinas, dikatakan adil apabila seseorang memperoleh hak dan kewajibannya menurut suatu kesamaan yang proporsional. Dikaitkan dengan kebijakan penanggulangan illegal fishing Indonesia saat ini, instrumen hukum telah memberikan landasan bagi nelayan lokal untuk memperoleh perlakuan yang sama dalam pengelolaan perikanan, termasuk terhadap ketentuan pidana yang menjeratnya. Namun kebijakan penanggulangan illegal fishing Indonesia saat ini membedakan perlakuan dalam hal penjatuhan pidana terhadap nelayan lokal dan nelayan asing pelaku tindak pidana illegal fishing. Sanksi pidana perampasan kemerdekaan (penjara dan kurungan) hanya berlaku bagi nelayan lokal dan belum menjangkau nelayan asing. Bagi nelayan asing pelaku illegal fishing hanya dapat dijatuhi pidana denda tanpa disertai pidana pengganti kurungan apabila denda tidak dibayar. Mak dikaitkan dengan konsep keadilan Thomas Aquinas, kebijakan penanggulangan illegal fishing yang direpresentasikan dalam Undang-Undang Perikanan belum memberikan keadilan. Ketidakadilan ini disebabkan karena politik hukum pembentukan Undang-Undang Perikanan yang lebih mengedepankan tindakan represif dari pada tindakan preventif dan rehabilitatif.

\section{DAFTAR PUSTAKA}

\section{Jurnal}

[1] Adlhiyati, Z., \& Achmad, A. (2019). Melacak Keadilan dalam Regulasi Poligami: Kajian Filsafat Keadilan Aristoteles, Thomas Aquinas, dan John Rawls. Undang: Jurnal Hukum, 2(2), 409-43. DOI: https://doi.org/10.22437/ujh.2.2.409-431, h. 412.

[2] Amin, M. (2014). Konsep Keadilan Dalam Perspektif Filsafat Hukum Islam. Al-Daulah: Jurnal Hukum dan Perundangan Islam,4(02), 322-343. DOI: https://doi.org/10.15642/ad.2014.4.02.322-343.

[3] Arum, G. A. (2019). Konsep Keadilan (Iustitia) Perspektif St. Thomas Aquinas dan Relevansinya Bagi Pemaknaan Sila V Pancasila. Lumen Veritatis: Jurnal Filsafat dan Teologi, 10(1), 23-44. DOI: https://doi.org/10.30822/lumenveritatis.v10i1.207.

[4] Dwisvimiar, I. (2011). Keadilan dalam perspektif filsafat ilmu hukum. Jurnal Dinamika Hukum, 11(3), 522-531. DOI: https://doi.org/10.20884/1.jdh.2011.11.3.179.

[5] Harahap, D. R. S. (2020). Kebijakan Formulasi Tindak Pidana Oleh Anak Yang Dapat Diupayakan Diversi Berdasarkan Aspek Keadilan Dan Tujuan Pemidanaan. Ilmu dan Budaya, 41(67).

[6] Harnoko, A. Y., \& Ratnawati, I. Y. (2015). Asas Proporsional dalam Perjanjian Waralaba (Franchise). Jurnal Hukum

Bisnis, 1(1). DOI:https://doi.org/10.33121/hukumbisnis.v1i1.54.

[7] Helmi, M. (2015). Konsep Keadilan Dalam Filsafat Hukum Dan Filsafat Hukum Islam. Mazahib, 14(2). DOI: https://doi.org/10.21093/mj/v14i2.342.

[8] Mashuri, M. (2017). Teori Keadilan Dalam Perlindungan Hukum Bagi Kepala Desa Dalam Melaksanakan Kebijakan Desa (Studi Kasus Putusan Perkara Nomor 66/Pid. Sus/Tpk/2015/PN. Sby). MIMBAR YUSTITIA, 1(1), 59-78.

[9] Nasution, B. J. (2014). Kajian Filosofis tentang Konsep Keadilan dari Pemikiran Klasik

45 Laliliyah, A dkk. (2016). Laporan Akhir Analisis dan Evaluasi Hukum dalam Rangka Pemberantasan Kegiatan Perikanan Liar (IUU Fishing). Jakarta: Pusat Analisis dan Evaluasi Hukum Nasional Badan Pembinaan Hukum Nasional Kementerian Hukum dan HAM RI, h. 40.

$$
\text { 133|SASI Vol. } 27 \text { No.2, April - Juni } 2021
$$


sampai Pemikiran Modern. Yustisia Jurnal Hukum, 3(2). DOI: https://doi.org/10.20961/yustisia.v3i2.11106.

[10] Nasution, B. J. (2016). Kajian Filosofis tentang Hukum dan Keadilan dari Pemikiran Klasik Sampai Pemikiran Modern. Al-Ihkam: Jurnal Hukum \& Pranata Sosial, 11(2), 247-274. DOI: 10.19105/al-ihkam.v11i2.936, h. 253.

[11]Pratasis, S. O. (2014). Implementasi Teori Keadilan Komutatif Terhadap Pelaku Pemerkosaan Menurut Pasal 285 KUHP. LEX ET SOCIETATIS, 2(5).

[12]Putra, S. D. E. (2016). Bingkai Keadilan Hukum Pancasila Dalam Perspektif Hukum Dan Relevansinya Dengan Keadilan Di Indonesia. Jurnal Ilmiah Pendidikan Pancasila dan Kewarganegaraan, 27(1). DOI: http://dx.doi.org/10.17977/jppkn.v27i1.5515.

[13]Ramon, T. (2019). Kriteria Keseimbangan Dalam Perjanjian Kredit Bank Untuk Mewujudkan Keadilan Komutatif. Jurnal Hukum IUS QUIA IUSTUM, 26(2), 372-390. DOI: https://doi.org/10.20885/iustum.vol26.iss2.art8.

[14] Siregar, C. (2014). Pancasila, Keadilan Sosial, dan Persatuan Indonesia. Humaniora, 5(1), 107-112.. DOI: https://doi.org/10.21512/humaniora.v5il.2988.

[15] Srisusilawati, P., \& Eprianti, N. (2017). Penerapan prinsip keadilan dalam akad mudharabah di lembaga keuangan syariah. Law and Justice, 2(1), 12-23.. DOI: https://doi.org/10.23917/laj.v2i1.4333.

[16] Suhardin, Y. (2009). Fenomena Mengabaikan Keadilan dalam Penegakan Hukum. Mimbar Hukum-Fakultas Hukum Universitas Gadjah Mada,21(2), 341-354. DOI: https://doi.org/10.22146/jmh.16261.

[17] Surajiyo, S. (2018). Keadilan Dalam Sistem Hukum Pancasila. IKRA-ITH HUMANIORA: Jurnal Sosial dan Humaniora, 2(3), 21-29.

[18] Suryawati, I. G. A. A., \& Santhiarsa, I. G. N. N. (2020). Literasi Budaya Bali: Kajian Filsafat Ilmu Tentang Keadilan Dalam Sistem Subak. Jurnal Nomosleca, 6(1). DOI: https://doi.org/10.26905/nomosleca.v6i1.3960.

[19] Sutiyoso, B. (2010). Mencari Format Ideal Keadilan Putusan dalam Peradilan. Jurnal Hukum Ius Quia Iustum, 17(2), 217-232. https://doi.org/10.20885/iustum.vol17.iss2.art5.

[20] Vieru, S. (2010). Aristotle's Influence on the Natural Law Theory of St Thomas Aquinas. The Western Australian Jurist, 1, 115-122.

[21] Wantu, F. M. (2013). Kendala Hakim Dalam Menciptakan Kepastian Hukum, Keadilan, dan Kemanfaatan di Peradilan Perdata. Mimbar Hukum-Fakultas Hukum Universitas Gadjah Mada, 25(2), 205-218. DOI: https://doi.org/10.22146/jmh.16092, h 208.

\section{Buku}

[22] Arifin, M. (1993). Teori dan Filsafat Hukum. Jakarta: Rajagrafindo Persada.

[23] Bushlack, T. J. (2011). Justice in the theology of Thomas Aquinas: Rediscovering civic virtue. University of Notre Dame.

[24]Erwin, M. (2016). Filsafat Hukum Refleksi Kritis terhadap Hukum Indonesia (dalam Dimensi Ide dan Aplikasi). Jakarta: Raja Grafindo Persada.

[25]Hernoko, A. Y. (2009). Perkembangan dan Dinamika Hukum Perdata Indonesia-Dalam Rangka Peringatan Ulang Tahun Ke-80 Prof. Dr. Mr. R. Soetojo Prawirihamidjojo, SH, Lutfansah Mediatama. Prof. Dr. Mr. R. Soetojo Prawirihamidjojo, SH, Surabaya: Lutfansah Mediatama.

[26] Indrati, Maria Farida S. (2007). Ilmu Perundang-Undangan: Proses Dan Teknik Pembentukannya, Yogyakarta: Kanisius.

[27]Lisska, A. J. (2015). The Philosophy of Law of Thomas Aquinas. In A Treatise of Legal Philosophy and General Jurisprudence (pp. 285-310). Dordrecht: Springer.

[28] Mertokusumo, S. (2010). Mengenal Hukum; Suatu Pengantar. Yogyakarta: Cahaya Atma Pustaka.

[29]Rahardjo, S. (2003). Sisi-sisi lain dari Hukum di Indonesia. Jakarta: Penerbit Buku 
Kompas.

[30] Sumaryono, E., \& Sardi, M. (2002). Etika \& hukum: relevansi teori hukum kodrat Thomas Aquinas. Jakarta: Kanisius.

[31] Sunatri, T. (2017). Optimalisasi Pelaksanaan Eksekusi Pidana Denda Dikaitkan Pasal 102 Undang-Undang Nomor 31 tahun 2004 Tentang Perikanan. Jakarta: MISWAR.

\section{Lain-Lain}

[32]Laliliyah, A dkk. (2016). Laporan Akhir Analisis dan Evaluasi Hukum dalam Rangka Pemberantasan Kegiatan Perikanan Liar (IUU Fishing). Jakarta: Pusat Analisis dan Evaluasi Hukum Nasional Badan Pembinaan Hukum Nasional Kementerian Hukum dan HAM RI, h. 40.

[33] Putra, A. P. (2015). Tanggung Jawab PT. PLN Terhadap Konsumen Akibat Pemadaman Listrik Ditinjau Dari UU No 8 Tahun 1999 Tentang Perlindungan Konsumen (Disertasi, Universitas Pembangunan Nasional Veteran Jakarta)

[34] Tim Penyusun. (2013). Naskah Akademik Hukum Kontrak. Jakarta: BPHN Kementerian Hukum dan HAM RI. 